medRxiv preprint doi: https://doi.org/10.1101/2021.09.14.21263530; this version posted September 22, 2021. The copyright holder for this preprint (which was not certified by peer review) is the author/funder, who has granted medRxiv a license to display the preprint in All rights reserved. No reuse allowed without permission.

\title{
Alterations in resting-state activity and functional connectivity in children with 22q11.2 deletion syndrome
}

Joanne L. Doherty*1,2, Adam C. Cunningham ${ }^{1}$, Samuel J.R.A. Chawner ${ }^{1}$, Hayley M. Moss ${ }^{1}$, Diana C. Dima ${ }^{2}$, David E. J. Linden ${ }^{1,2}$, Michael J. Owen ${ }^{1}$, Marianne B.M. van den Bree ${ }^{1}$, and Krish D. Singh ${ }^{2}$

1. Medical Research Council Centre for Neuropsychiatric Genetics and Genomics, Division of Psychological Medicine and Clinical Neurosciences, School of Medicine, Cardiff University, Cardiff, United Kingdom

2. Cardiff University Brain Research Imaging Centre (CUBRIC), School of Psychology, Cardiff University, Cardiff, United Kingdom

${ }^{*}$ Corresponding author

Email: dohertyjl@cardiff.ac.uk

Address: MRC Centre for Neuropsychiatric Genetics and Genomics, Division of Psychological Medicine and Clinical Neurosciences, School of Medicine, Cardiff University, Hadyn Ellis Building, Maindy Road, Cardiff, CF24 4HQ

NOTE: This preprint reports new research that has not been certified by peer review and should not be used to guide clinical practice. 
medRxiv preprint doi: https://doi.org/10.1101/2021.09.14.21263530; this version posted September 22, 2021. The copyright holder for this preprint (which was not certified by peer review) is the author/funder, who has granted medRxiv a license to display the preprint in All rights reserved. No reuse allowed without permission.

\section{Abstract}

\section{Background}

While genetic risk factors for psychiatric and neurodevelopmental disorders have been identified, the neurobiological route from genetic risk to neuropsychiatric outcome remains unclear. 22q11.2 deletion syndrome (22q11.2DS) is a copy number variant (CNV) syndrome associated with high rates of neurodevelopmental and psychiatric disorders including autism spectrum disorder (ASD), attention deficit hyperactivity disorder (ADHD) and schizophrenia. Alterations in neural integration and cortical connectivity have been linked to the spectrum of neuropsychiatric disorders seen in 22q11.2DS and may be a mechanism by which the CNV acts to increase risk. Despite this, few studies have investigated electrophysiological connectivity in this high-risk group. Studying children with 22q11.2DS provides a unique paradigm to identify brain markers of neurodevelopmental impairment and to relate these to underlying biology.

\section{Methods}

Magnetoencephalography (MEG) was used to investigate resting-state cortical oscillatory patterns in 34 children with 22 q11.2DS and 25 controls aged 10-17 years old. Oscillatory activity and functional connectivity across six frequency bands were compared between groups. Regression analyses were used to explore the relationships between these measures, IQ and neurodevelopmental symptoms. 
medRxiv preprint doi: https://doi.org/10.1101/2021.09.14.21263530; this version posted September 22, 2021. The copyright holder for this preprint (which was not certified by peer review) is the author/funder, who has granted medRxiv a license to display the preprint in All rights reserved. No reuse allowed without permission.

\section{Results}

Children with 22q11.2DS had atypical oscillatory activity and functional connectivity across multiple frequency bands (delta, beta and gamma bands). In the 22q11.2DS group, low frequency (alpha band) activity was negatively associated with cognitive ability and positively associated with ASD and ADHD symptoms. Frontal high frequency (gamma band) activity and connectivity were positively associated with ASD and ADHD symptoms, while posterior gamma activity was negatively associated with ASD symptoms.

\section{Conclusions}

These findings highlight that haploinsufficiency at the $22 q 11.2$ locus alters both local and long-range cortical circuitry, which could be a mechanism underlying neurodevelopmental vulnerability in this high risk group.

\section{Introduction}

Copy number variants (CNVs) are submicroscopic alterations (such as deletions or duplications) of segments of chromosomes, which constitute a major source of variation between individuals. CNVs can result in chromosomes having too many or too few dosagesensitive genes. These changes may be advantageous, indeed CNVs are thought to have been important in human evolution (1); however, they may also have a negative impact on human development (2).

22q11.2 deletion syndrome (22q11.2DS), also known as velocardiofacial syndrome (VCFS) and Di George syndrome, is one of the most common copy number deletion syndromes, affecting 
medRxiv preprint doi: https://doi.org/10.1101/2021.09.14.21263530; this version posted September 22, 2021. The copyright holder for this preprint (which was not certified by peer review) is the author/funder, who has granted medRxiv a license to display the preprint in

All rights reserved. No reuse allowed without permission.

at least 1 in 4000 live births (3-5). It results from a 1.5-3Mb deletion at region q11.2 on chromosome 22. As with many CNV syndromes, the 22q11.2DS phenotype is extremely variable, involving multiple organ systems (6). The mechanisms underlying the pleiotropy and phenotypic variability in 22q11.2DS are, as yet, not well understood. Neurodevelopmental, behavioral, emotional, cognitive and psychiatric problems are very common in 22q11.2DS (710). The 22q11.2 International Consortium on Brain and Behavior study of over 1400 individuals with 22 q11.2DS found that $21 \%$ of children with the deletion have ASD, $32 \%$ have ADHD and up to $30 \%$ develop schizophrenia in adulthood (11).

The $22 q 11.2$ region contains approximately 60 genes, but as yet no gene or combination of genes has been found to be either necessary or sufficient for the neurodevelopmental phenotypes observed in the deletion syndrome. It has been proposed that 22q11.2DS and other neurodevelopmental CNVs increase risk of psychopathology by affecting neuronal integration with downstream effects on local and long-range cortical networks (12). There is mounting evidence from animal models for abnormal neuronal structure, function and migration (13-15), as well as abnormal cortical network activity in 22q11.2DS $(16,17)$. In humans, postmortem studies have also found abnormal neuronal morphology and migration in 22q11.2DS $(13-15,18,19)$, while structural magnetic resonance imaging (MRI) studies report reductions in cortical surface area (20), subcortical volumes (21) and white matter diffusivity (22). Furthermore, resting-state functional MRI (fMRI) studies have found alterations across several brain networks including the default-mode, sensorimotor, visuospatial, self-referential and visual networks (23-27). Alterations in neurotransmitter concentrations have also been reported in adults with 22q11.2DS and these have been associated with psychotic symptoms $(28,29)$. 
medRxiv preprint doi: https://doi.org/10.1101/2021.09.14.21263530; this version posted September 22, 2021. The copyright holder for this preprint (which was not certified by peer review) is the author/funder, who has granted medRxiv a license to display the preprint in All rights reserved. No reuse allowed without permission.

Synchronous oscillatory activity in the cortex reflects neuronal integration and is thought to facilitate communication within and between brain regions $(30,31)$. It can be measured noninvasively in humans using EEG and MEG. Atypical oscillatory patterns have been observed in idiopathic ASD (32-34), ADHD (35-37) and schizophrenia (38-40). Despite the proposed neuronal integration deficits in 22q11.2DS and other neurodevelopmental CNVs, there have been relatively few studies of cortical oscillations in these high-risk groups. In a recent restingstate MEG study in adult CNV carriers, we found common patterns of oscillatory dysconnectivity across nine different neurodevelopmental CNV loci, including 22q11.2DS, suggesting a putative mechanism by which neurodevelopmental CNVs could increase risk of psychopathology (41). Due to the relatively small numbers of participants with each CNV, it was not possible to explore the associations between oscillatory activity and neurodevelopmental symptoms or psychopathology. To our knowledge, there have been no previous studies of resting-state cortical oscillations in children with 22q11.2DS. In the present study, we focused exclusively on children with 22q11.2DS, to investigate the impact of this genetic risk factor on oscillatory activity in the developing brain and to explore associations with cognitive function and neurodevelopmental symptoms.

\section{Methods and Materials}

\section{Participants}

Participants were recruited through National Health Service (NHS) genetics clinics and patient support groups in the United Kingdom. 38 children aged between 10-17 years old with a diagnosis of 22q11.2DS and 26 unaffected siblings of children with neurodevelopmental CNVs 
medRxiv preprint doi: https://doi.org/10.1101/2021.09.14.21263530; this version posted September 22, 2021. The copyright holder for this preprint (which was not certified by peer review) is the author/funder, who has granted medRxiv a license to display the preprint in All rights reserved. No reuse allowed without permission.

(controls) were recruited to the study. Written consent was obtained in accordance with The Code of Ethics of the World Medical Association (Declaration of Helsinki) and all procedures were approved by the South East Wales NHS Research Ethics Committee. Participants over the age of 16 years old with capacity to consent gave written informed consent to participate in the study. Children under the age of 16 years old or those over the age of 16 who lacked capacity to consent for themselves gave written and/or verbal assent to take part and their parents or carers provided consent for their participation. Participants were excluded from the study if they had photosensitive epilepsy, orthodontic braces or metallic implants/prostheses in the upper half of the body. Participants taking psychotropic medication were excluded from the analyses $(n=1)$.

\section{Genotyping}

CNV status was confirmed for all participants. Affected children were excluded from taking part in the study if a 22q11.2 deletion was not confirmed either by in-house testing at the MRC Centre for Neuropsychiatric Genetics and Genomics at Cardiff University or by clinical genetics report. All control participants had in-house microarray testing and were excluded from the analysis if they carried a neurodevelopmental CNV as defined in (42) $(n=1)$. Genotyping was carried out using the Illumina HumanCoreExome whole genome SNP array, which contains 27000 additional genetic variants at loci previously linked to neurodevelopmental disorders, including CNVs.

\section{Cognition and psychopathology}

Psychiatric and cognitive data were collected from participating children and their primary caregiver by trained research psychologists, supervised by child and adolescent psychiatrists. 
medRxiv preprint doi: https://doi.org/10.1101/2021.09.14.21263530; this version posted September 22, 2021. The copyright holder for this preprint (which was not certified by peer review) is the author/funder, who has granted medRxiv a license to display the preprint in All rights reserved. No reuse allowed without permission.

Psychiatric interviews were conducted with the primary carer using the Child and Adolescent Psychiatric Assessment [CAPA; (43)] to derive DSM-5 (44) ADHD diagnoses and symptom counts. The Social Communication Questionnaire [SCQ; 45$)]$ was completed by the primary carer and used to assess ASD symptoms. Children's full-scale IQ scores were obtained using the Wechsler Abbreviated Scale of Intelligence [WASI; (46)]. Further details about the clinical and cognitive phenotyping protocol have previously been reported (9).

\section{Data acquisition}

Five minute whole-head MEG recordings were acquired at a $1200 \mathrm{~Hz}$ sample rate using a 275 channel CTF radial gradiometer system. An additional 29 reference channels were recorded for noise cancellation purposes. Primary sensors were analysed as synthetic third-order gradiometers (47). Participants were seated upright in the MEG system during the recordings and were instructed to keep their eyes open and to attend to a red fixation point presented on a mean luminance background using a Mitsubishi Diamond Pro 2070 monitor $(100 \mathrm{~Hz}$ frame rate) or PROPixx LCD projector $(120 \mathrm{~Hz}$ frame rate). Electromagnetic coils were placed at three fiducial locations (bilateral preauricular regions and nasion) and their position relative to the MEG sensors was localised at the beginning and end of each recording. Relative head position at the beginning and end of the recording was used as a proxy measure of participant head motion.

After the recordings, MEG data were down-sampled to $600 \mathrm{~Hz}$, band-pass filtered at $1-150 \mathrm{~Hz}$ and segmented into 2 s epochs, generating 150 trials per participant. Data were then visually inspected for gross artefacts such as motion, muscular contraction and eye movements. Trials 
medRxiv preprint doi: https://doi.org/10.1101/2021.09.14.21263530; this version posted September 22, 2021. The copyright holder for this preprint (which was not certified by peer review) is the author/funder, who has granted medRxiv a license to display the preprint in All rights reserved. No reuse allowed without permission.

containing such artefacts were removed from the dataset and excluded from further analysis. Participants with head motion greater than $30 \mathrm{~mm}$ or with greater than half of their trials containing artefacts were excluded from further analysis $(n=4)$.

After quality control, data from 34 children with 22q11.2DS (92\%, 17 female) and 25 controls $(100 \%, 10$ female) remained and were included in the subsequent analyses. There were no significant between-group differences in head motion (median=4.65mm (IQR=5.4mm) in children with $22 \mathrm{q} 11.2 \mathrm{DS}$, median $=2.9 \mathrm{~mm}(\mathrm{IQR}=4.6 \mathrm{~mm})$ in controls, $\mathrm{p}=0.61)$ or the number of trials after artefact rejection (median=131 $(\mathrm{IQR}=34)$ in children with 22q11.2DS, median $=133$ $(I Q R=29)$ in controls, $p=0.22)$.

Where possible, T1-weighted MRI structural images were acquired either with a 3D fast spoiled gradient echo (FSPGR) sequence on a General Electric HDx MRI system (TR=7.8ms, $\mathrm{TE}=3.0 \mathrm{~ms}$, voxel size $=1 \mathrm{~mm}$ isotropic) or a $3 \mathrm{D}$ magnetization prepared rapid acquisition gradient echo (MP-RAGE) sequence on a Siemens Prisma MAGNETOM MRI system (TR=2.3ms, $\mathrm{TE}=3.06 \mathrm{~ms}$ voxel size $=1 \mathrm{~mm}$ isotropic). Co-registration was performed by manually labelling the fiducial points on each participant's MRI using the software package MRIViewer. T1 MRI data were not available for 15 participants due to MRI contraindications or poor data quality (e.g. due to participant head motion). For these participants, an appropriate MRI scan was selected from the available data by comparing the relative distances between the fiducial points for each participant and matching these with another participant's dataset. The resulting co-registrations were visually inspected and a good quality match was achieved in all cases. 
medRxiv preprint doi: https://doi.org/10.1101/2021.09.14.21263530; this version posted September 22, 2021. The copyright holder for this preprint (which was not certified by peer review) is the author/funder, who has granted medRxiv a license to display the preprint in All rights reserved. No reuse allowed without permission.

\section{MEG Analysis: Activity and connectivity estimation}

The analysis pipeline is described in more detail in supplementary material and summarized in Figure 1 below. Source reconstruction was performed using a linearly-constrained minimum variance (LCMV) beamformer in FieldTrip (version 20161011, www.fieldtriptoolbox.org, (48). Beamforming was performed in each of six distinct frequency bands using conventional definitions: delta (1-4 Hz), theta $(4-8 \mathrm{~Hz})$, alpha $(8-13 \mathrm{~Hz})$, beta (13$30 \mathrm{~Hz})$, low gamma $(40-60 \mathrm{~Hz})$ and high gamma $(60-90 \mathrm{~Hz})$. Beamformer weights were used to derive an estimated activity timeseries at each voxel on a $6 \mathrm{~mm}$ grid and for each trial. These trial timeseries were concatenated to form a single timeseries for each grid voxel and then taken forward for both activity and connectivity analyses.

For each of the reconstructed grid positions, a measure of neural activity was derived in each frequency band by first computing the amplitude envelope of the virtual-sensor timeseries using the absolute value of the analytic function transform of the raw timeseries (using Matlab's hilbert function) and then converting this to a single activity measure that summarizes how variable this envelope is over the entire resting-state run. To do this we calculated the coefficient-of-variation of the envelope. This normalized measure has the advantage of correcting for the known biases introduced by the sensitivity of beamformer weights to variations in the signal to noise ratio $(S N R)$ of the data $(48,49)$. The end result is a $6 \mathrm{~mm}$ isotropic activity map for each participant and each frequency band.

Functional connectivity was computed using the amplitude-envelope correlation (AEC) metric. This metric has previously been shown to be both robust and repeatable (50). The analysis pipeline has previously been described (48). First, spatial down-sampling to the 90 
medRxiv preprint doi: https://doi.org/10.1101/2021.09.14.21263530; this version posted September 22, 2021. The copyright holder for this preprint (which was not certified by peer review) is the author/funder, who has granted medRxiv a license to display the preprint in All rights reserved. No reuse allowed without permission.

regions of the Automated Anatomical Labelling (AAL90) atlas was performed (51). The temporal activity of each of these 90 sources was then orthogonalized with respect to each other in order to suppress any zero-time-lag correlation due to signal leakage (52). Next, the amplitude (Hilbert) envelopes of each AAL90 region were extracted using the absolute of the (complex) analytical signal derived by the hilbert function in MATLAB. These amplitude envelopes were then down-sampled to a temporal resolution of $1 \mathrm{~s}$ in order to study connectivity mediated by slow amplitude envelope changes (53). To obtain connectivity matrices, pairwise correlations were calculated between the 90 Hilbert envelopes, yielding 4005 unique correlations for each frequency band for each participant. Each of these correlation coefficients was then transformed to a variance-normalized Fisher z-statistic. This made the correlations suitable for further statistical analysis and corrected for the varying length of the final time series for each participant.

\section{MEG analysis: Activity and connectivity component estimation}

At the end of the above analysis procedures, each participant had 6 activity maps and 6 connectivity matrices (one for each frequency band). Each activity map had 5061 voxels and each connectivity map had 4005 unique connection values. In order to reduce the dimensionality of these features before statistical analyses, we used a data-driven analysis of the principal components using non-negative matrix factorization (Matlab: nnmf). Recently, non-negative matrix factorization has been successfully used to show cohort differences in a MEG study of schizophrenia (54) and in comparing structural and functional connectivity components in healthy individuals (55). We iteratively increased the number of components and tested what proportion of our cohort had non-zero values. We required each component to be represented in at least $50 \%$ of our participants and for the mean number of participants 
medRxiv preprint doi: https://doi.org/10.1101/2021.09.14.21263530; this version posted September 22, 2021. The copyright holder for this preprint (which was not certified by peer review) is the author/funder, who has granted medRxiv a license to display the preprint in All rights reserved. No reuse allowed without permission.

represented to be at least $70 \%$. For each of the final components identified, we projected each individual's data on to these networks to get a single component 'strength' for each person. For each of the 12 metrics we have in each person ( 6 activity and 6 connectivity), we performed NNMF separately. As shown in figures 1,2 and 7, each participant's combined activity and connectivity profile, across all 6 bands, was effectively summarised by just 79 values. It is these values that were taken forward for statistical analysis.

\section{Statistical analyses of NNMF derived component scores}

Each of the component weightings described above was used in an analysis to determine whether their magnitude was predicted by a set of exploratory variables consisting of group status (22q11DS or control), IQ, SCQ score and ADHD symptoms. Due to differing IQ distributions in the two groups, associations with IQ were explored in each group separately. This analysis was done by a set of univariate robust general linear modelling tests, using Matlab's fit/m function. In each linear-model fit age, sex and number of MEG trials were included in the models as covariates. For linear models exploring the associations with SCQ scores and ADHD symptoms, IQ was included as an additional covariate. In each test, we assessed the significance of the principal variable in explaining variance in the residuals. Effect-sizes for the principal variable of interest were calculated using standardised-beta parameters and assessed for significance using $p$-values and $95 \%$ confidence intervals. Bonferroni correction was applied for the number of components tested within each type (activity/connectivity) and frequency band. 
medRxiv preprint doi: https://doi.org/10.1101/2021.09.14.21263530; this version posted September 22, 2021. The copyright holder for this preprint (which was not certified by peer review) is the author/funder, who has granted medRxiv a license to display the preprint in perpetuity.

All rights reserved. No reuse allowed without permission.

Figure 1. MEG Analysis pipeline

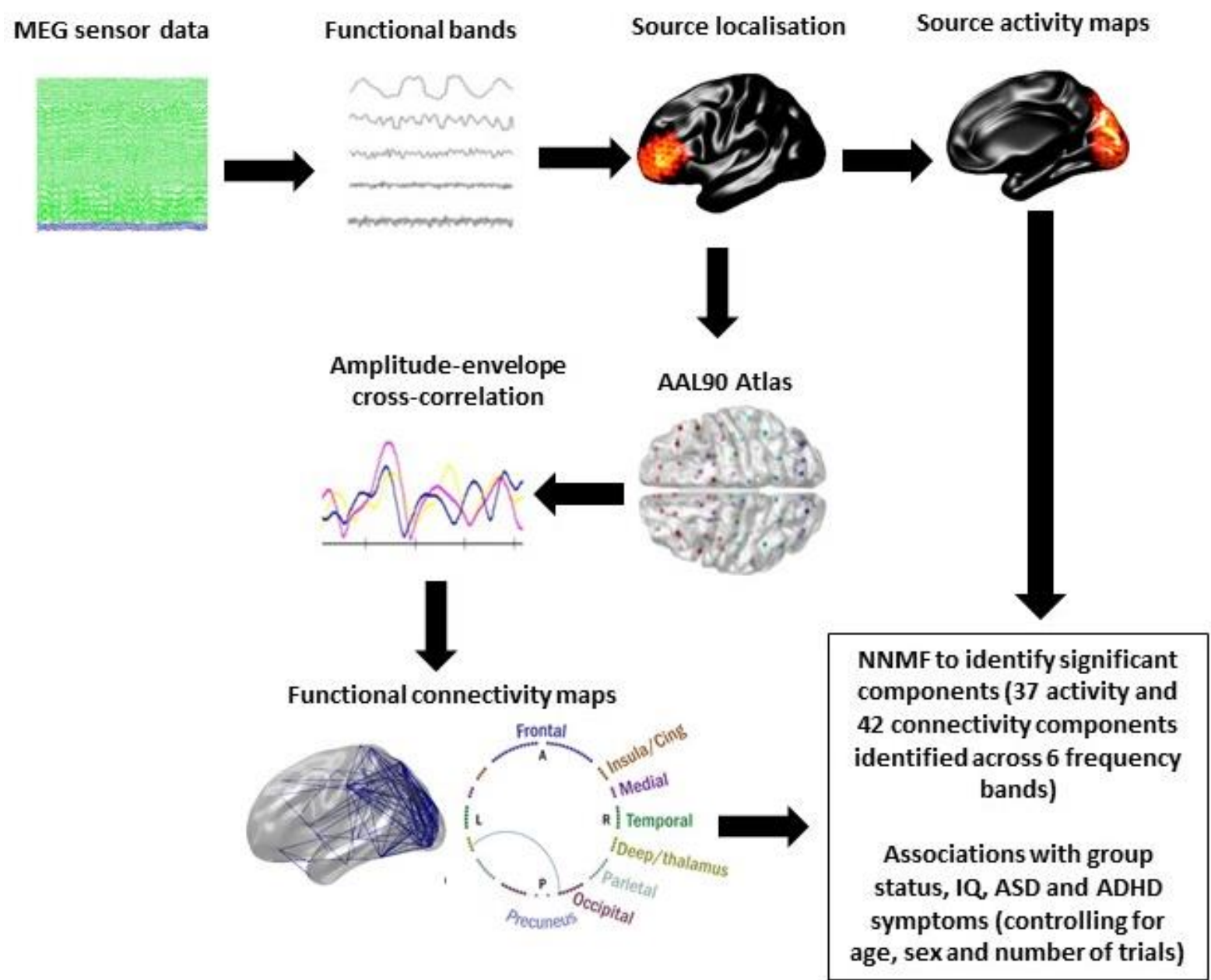

Figure 1. Overview of the MEG analysis pipeline. Sensor level MEG data were filtered into the six frequency bands of interest. Source localization was performed for each participant and each frequency band using a linearly-constrained minimum variance (LCMV) beamformer. Source activity was estimated for each participant and frequency band by calculating the temporal coefficient of variation (CoV) of the Hilbert envelope. For functional connectivity estimates, data were first down-sampled to the 90 regions of the Automated Anatomical Labelling (AAL90) atlas. The temporal activity of each of these 90 sources was then orthogonalized and the Hilbert envelopes of each AAL90 region were extracted. These amplitude envelopes were then down-sampled to a temporal resolution of $1 \mathrm{~s}$ and a median spike removal filter was applied. Pairwise correlations were calculated between the 90 Hilbert envelopes, for each frequency band and each participant. Non-negative matrix factorization was performed to identify the principal components for each of the six frequency bands of interest. This reduced the data to 79 components ( 37 activity components and 42 connectivity components) that were taken forward for further analysis. Relationships between the components, group status, IQ and neurodevelopmental symptoms were explored using regression models with age, sex and number of MEG trials included in the models as covariates. 
medRxiv preprint doi: https://doi.org/10.1101/2021.09.14.21263530; this version posted September 22, 2021. The copyright holder for this preprint (which was not certified by peer review) is the author/funder, who has granted medRxiv a license to display the preprint in

All rights reserved. No reuse allowed without permission.

\section{Results}

\section{Participant characteristics}

Table 1 shows demographic, cognitive and clinical characteristics of the 34 children with 22q11.2DS and 25 controls who were included in the analyses. Children with 22q11.2DS had full-scale IQ scores that were shifted approximately 30 points to the left of typically developing controls. $29.4 \%$ of children with 22q11.2DS scored above $15 / 40$ in the SCQ, which is a commonly used screening cut-off for a likely ASD diagnosis (57). $17.6 \%$ of children with 22q11.2DS met DSM-5 criteria for ADHD on the basis of symptoms reported in the CAPA. No controls met criteria for either ASD or ADHD diagnoses.

Table 1 Participant characteristics

\begin{tabular}{|c|c|c|c|c|}
\hline & 22q11.2DS & Controls & $\begin{array}{l}\text { Test } \\
\text { statistic } \\
\left(t / \chi^{2}\right)\end{array}$ & $\mathbf{P}$ \\
\hline $\begin{array}{l}\text { Age, mean in years } \\
\text { (range, SD) }\end{array}$ & $\begin{array}{l}13.5 \\
(10.5-17.5,1.9)\end{array}$ & $\begin{array}{l}14.4 \\
(10.5-17.9,1.8)\end{array}$ & -1.83 & 0.07 \\
\hline $\begin{array}{l}\text { Gender, \% female } \\
\text { (n) }\end{array}$ & $\begin{array}{l}50 \\
(17)\end{array}$ & $\begin{array}{l}56 \\
(14)\end{array}$ & 0.04 & 0.85 \\
\hline $\begin{array}{l}\text { Handedness, \% right } \\
\text { (n) }\end{array}$ & $\begin{array}{l}76.5 \\
(26)\end{array}$ & $\begin{array}{l}76.0 \\
(19)\end{array}$ & $<0.01$ & 1.00 \\
\hline $\begin{array}{l}\text { FSIQ score, mean } \\
\text { (range, SD) }\end{array}$ & $\begin{array}{l}74.4 \\
(53-117,12.9)\end{array}$ & $\begin{array}{l}107.4 \\
(86-139,11.0)\end{array}$ & 10.45 & $\begin{array}{l}1.3 \times 10^{-} \\
14\end{array}$ \\
\hline $\begin{array}{l}\text { SCQ score, mean } \\
\text { (range, SD) }\end{array}$ & $\begin{array}{l}11.0 \\
(3-25,6.4)\end{array}$ & $\begin{array}{l}2.4 \\
(0-9,3.1)\end{array}$ & 6.76 & $\begin{array}{l}1.32 \times 10^{-} \\
8\end{array}$ \\
\hline $\begin{array}{l}\text { Likely ASD diagnosis, \% } \\
\text { (n) }\end{array}$ & $\begin{array}{l}29.4 \\
(10)\end{array}$ & $\begin{array}{l}0 \\
(0)\end{array}$ & $*$ & $*$ \\
\hline $\begin{array}{l}\text { ADHD symptom score, mean } \\
\text { (range, SD) }\end{array}$ & $\begin{array}{l}4.1 \\
(0-13,4.2)\end{array}$ & $\begin{array}{l}0.3 \\
(0-3,0.7)\end{array}$ & 5.33 & $\begin{array}{l}5.42 \times 10^{-} \\
6\end{array}$ \\
\hline $\begin{array}{l}\text { Likely ADHD diagnosis, \% } \\
\text { (n) }\end{array}$ & $\begin{array}{l}17.6 \\
(6)\end{array}$ & $\begin{array}{l}0 \\
(0)\end{array}$ & $*$ & $*$ \\
\hline
\end{tabular}

*Unable to calculate test statistic $\left(\chi^{2}\right)$ or $p$ value due to zero cell count in controls 
medRxiv preprint doi: https://doi.org/10.1101/2021.09.14.21263530; this version posted September 22, 2021. The copyright holder for this preprint (which was not certified by peer review) is the author/funder, who has granted medRxiv a license to display the preprint in All rights reserved. No reuse allowed without permission.

\section{Source activity}

Figure 2 shows the significant components identified in the analysis of source activity for the between-group comparisons and the associations with IQ and neurodevelopmental symptoms. For each of the six frequency bands investigated, several components were identified. The components showing significant associations with group status, IQ (shown separately for children with 22q11.2DS and controls) and ADHD/ASD symptoms in children with 22q11.2DS are shown in figure 2, with red indicating a positive association and blue a negative association. The standardised $\beta$ value for the regressions was used as a marker of effect size.

Figure 2. Source activity across the six frequency bands of interest and associations with group status, IQ and neurodevelopmental symptoms

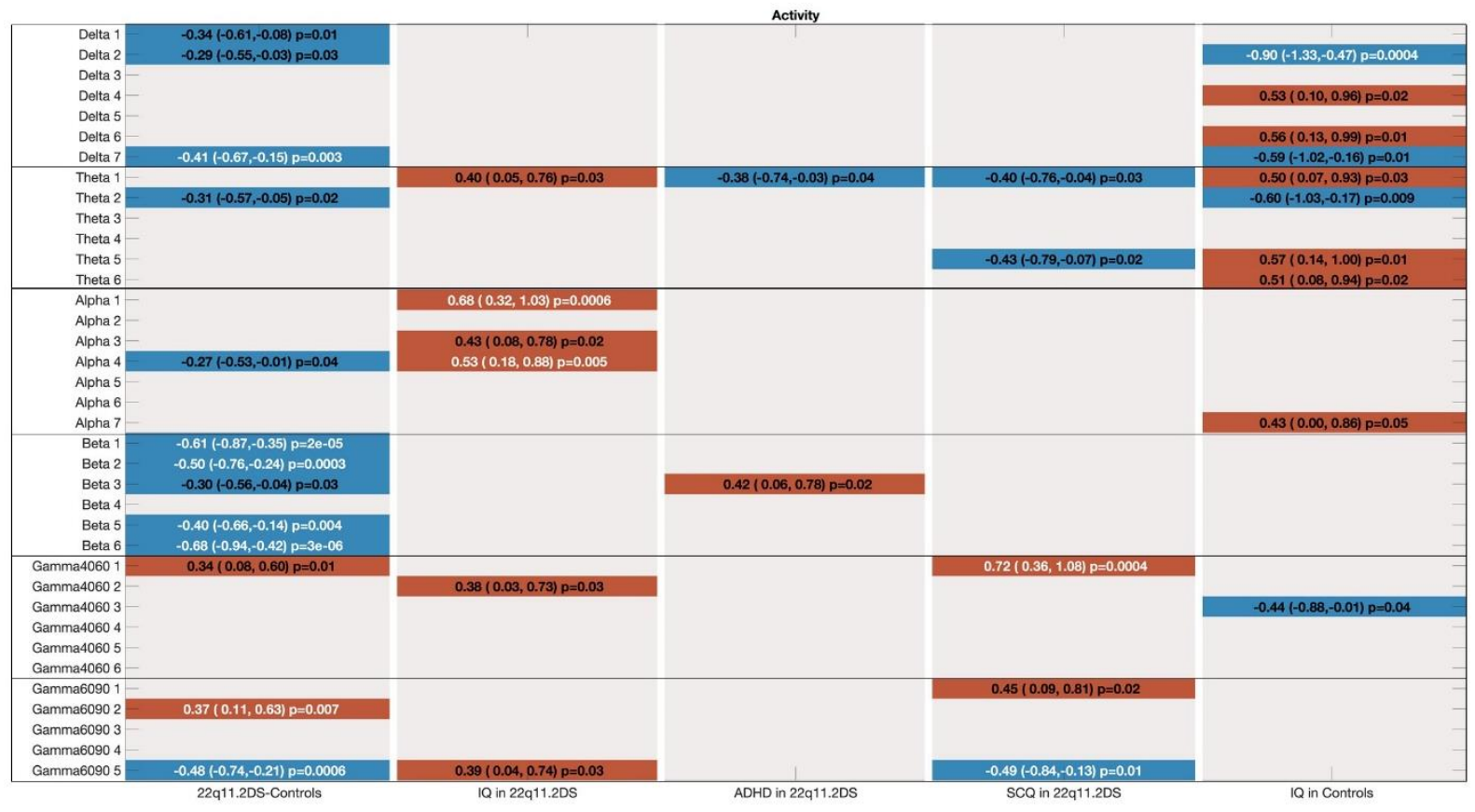

Figure 2. Significant associations between group status, $I Q$, neurodevelopmental symptoms and source activity for each of the six frequency bands of interest. Components with positive associations are shown in red, while negative associations are shown in blue. The associations surviving Bonferroni correction for the six frequency bands studied are highlighted in white text. Associations are shown by standardised $\beta$ values, confidence intervals and $p$ values. Age and sex were included in each model as covariates, IQ was included as an additional covariate in models testing associations with SCQ and ADHD scores. 
medRxiv preprint doi: https://doi.org/10.1101/2021.09.14.21263530; this version posted September 22, 2021. The copyright holder for this preprint (which was not certified by peer review) is the author/funder, who has granted medRxiv a license to display the preprint in

All rights reserved. No reuse allowed without permission.

As can be seen in figure 2, significant between-group differences in source activity were evident in the beta, delta and high gamma bands. In the beta band, four components were identified as having significantly reduced oscillatory activity in children with 22q11.2DS compared to controls, with moderate to strong effect sizes of between -0.40 to -0.68 . These components were located in occipital and temporoparietal regions (see figure 3).

Figure 3. Beta band source activity differences between children with 22q11.2DS and controls

Beta 1
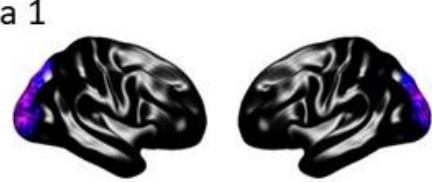

Beta 2
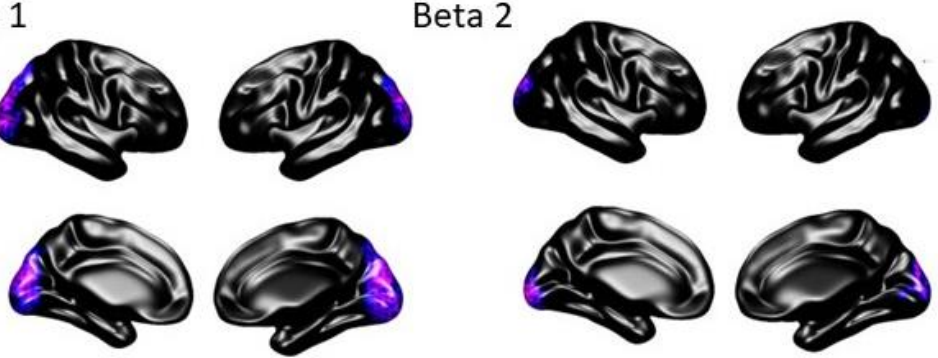

Beta 5

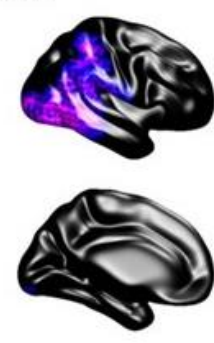

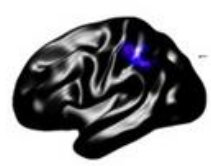

Beta 6
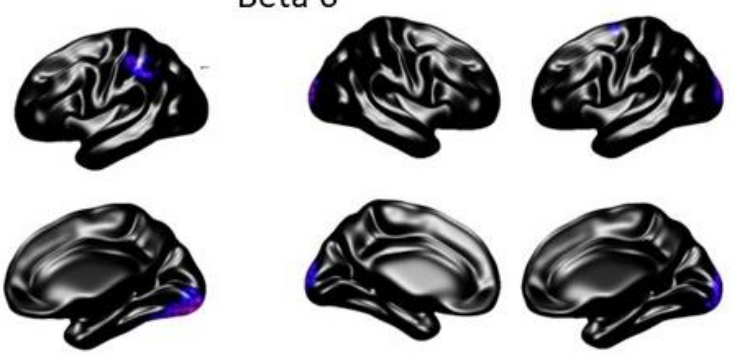

Figure 3. Locations of the four components showing significant between-group differences in beta band activity between children with 22q11.2DS and controls. Purple indicates reduced activity and orange indicates increased activity. Effect sizes: Beta $1=-0.61(p=0.000023)$, Beta $2=-0.50(p=0.000332)$, Beta $5=-$ $0.40(p=0.003757)$ and Beta $6=-0.68(P=0.000003)$. Age and sex are included in the model as covariates.

Delta band activity in the medial frontal cortex was reduced in children with 22q11.2DS (effect size $-0.41, p=0.0027$, figure 4$)$. In the high gamma band, there were two components with moderate effect sizes. High gamma oscillatory activity was significantly lower in the occipital lobes (effect size -0.48 ) but significantly higher in the frontal lobes of children with 22q11.2DS 
medRxiv preprint doi: https://doi.org/10.1101/2021.09.14.21263530; this version posted September 22, 2021. The copyright holder for this preprint (which was not certified by peer review) is the author/funder, who has granted medRxiv a license to display the preprint in perpetuity.

All rights reserved. No reuse allowed without permission.

(effect size $=0.37$, figure 4 ). There were no statistically significant differences in oscillatory activity or functional connectivity in other frequency bands.

Figure 4. Delta and high gamma band source activity differences between children with 22q11.2DS and controls

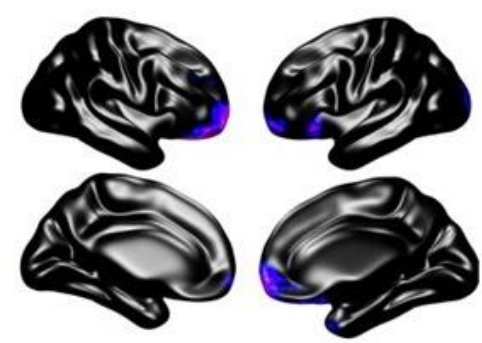

Delta 7

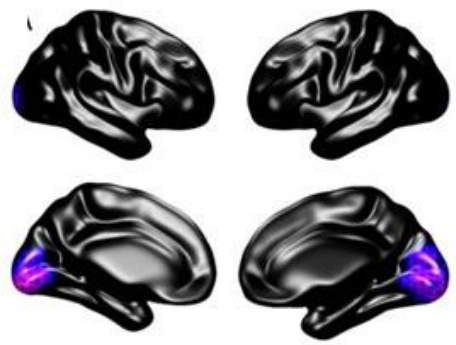

High gamma 5
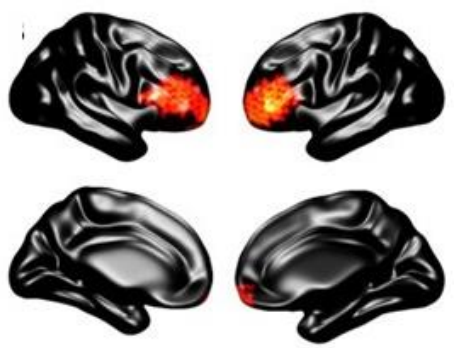

High gamma 2

Figure 4. Locations of the delta and high gamma components showing significant between-group differences in source activity between children with 22q11.2DS and controls. Purple indicates reduced activity and orange indicates increased activity. Effect sizes: Delta $7=-0.41(p=0.0027)$, High gamma $5=-0.48(p=0.000615)$ and high gamma $2=0.37(p=0.006592)$. Age and sex are included in the model as covariates.

\section{Associations between source activity, IQ and neurodevelopmental symptoms}

In children with 22q11.2DS, IQ was positively associated with two alpha band components, located in the occipital and parietal lobes, while in controls, IQ was negatively associated with delta band activity in frontotemporal regions. 
medRxiv preprint doi: https://doi.org/10.1101/2021.09.14.21263530; this version posted September 22, 2021. The copyright holder for this preprint (which was not certified by peer review) is the author/funder, who has granted medRxiv a license to display the preprint in perpetuity.

All rights reserved. No reuse allowed without permission.

\section{Figure 5. Associations between source activity and IQ in children with 22q11.2DS and} controls

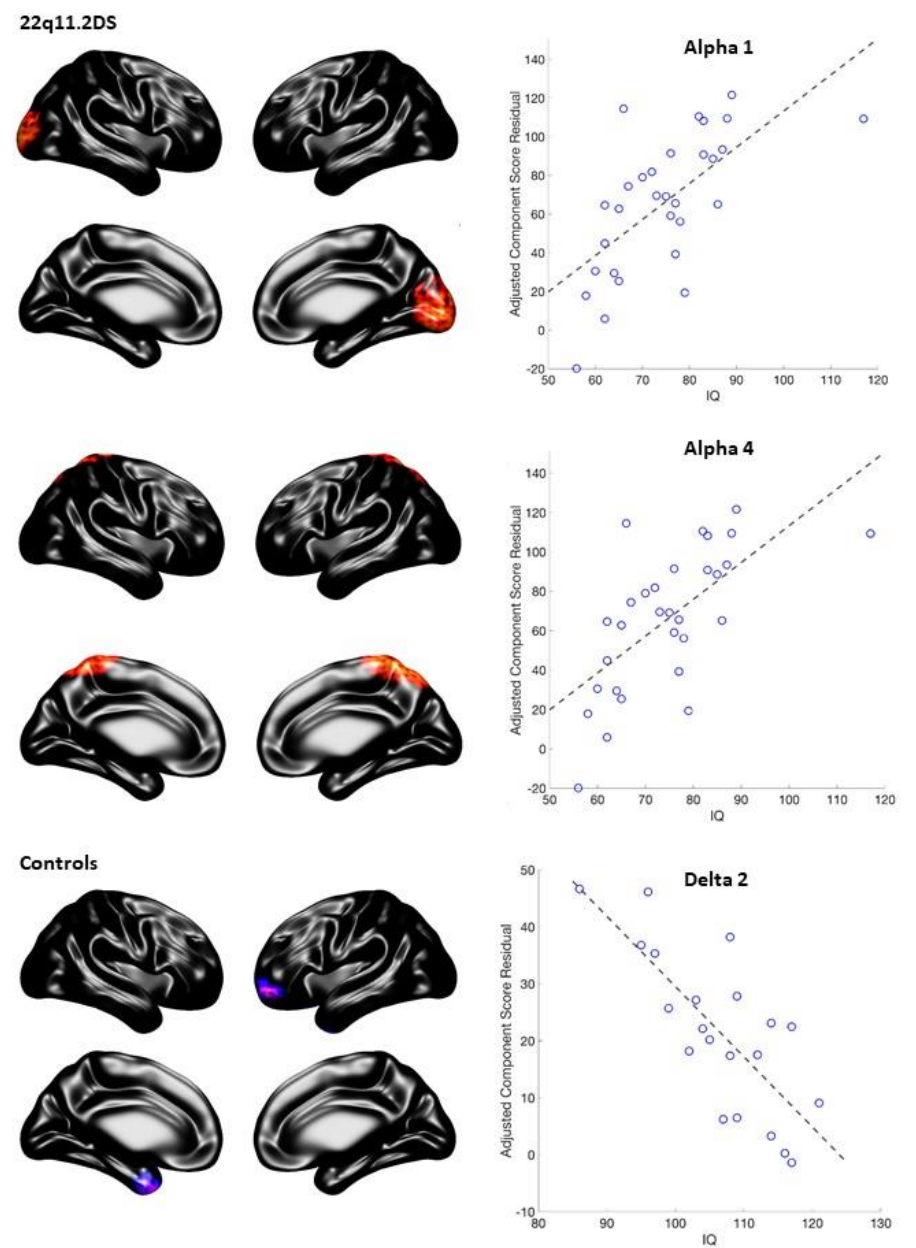

Figure 5. Relationships between IQ and source activity in children with 22q11.2DS and controls, controlling for age, sex and number of trials. Purple indicates reduced activity and orange indicates increased activity. Effect sizes: Alpha $1(22 q 11.2 D S)=0.68(p=0.00058)$, Alpha $4(22 q 11.2 D S)=0.53(p=0.0046)$ and delta 2 (controls $)=0.88$ $(p=0.00044)$.

There was a significant relationship between gamma oscillatory activity and ASD symptoms in children with 22q11.2DS, with the severity of social communication difficulties being positively associated with frontal gamma activity (effect size $0.72, p=0.0004$ ) and negatively associated with occipital gamma activity (effect size $-0.49, p=0.01$ ). There were no significant associations between source activity and ADHD symptoms that survived correction for multiple comparisons across the six frequency bands that were studied. 
medRxiv preprint doi: https://doi.org/10.1101/2021.09.14.21263530; this version posted September 22, 2021. The copyright holder for this preprint (which was not certified by peer review) is the author/funder, who has granted medRxiv a license to display the preprint in

All rights reserved. No reuse allowed without permission.

Figure 6. Association between gamma activity and social communication questionnaire scores

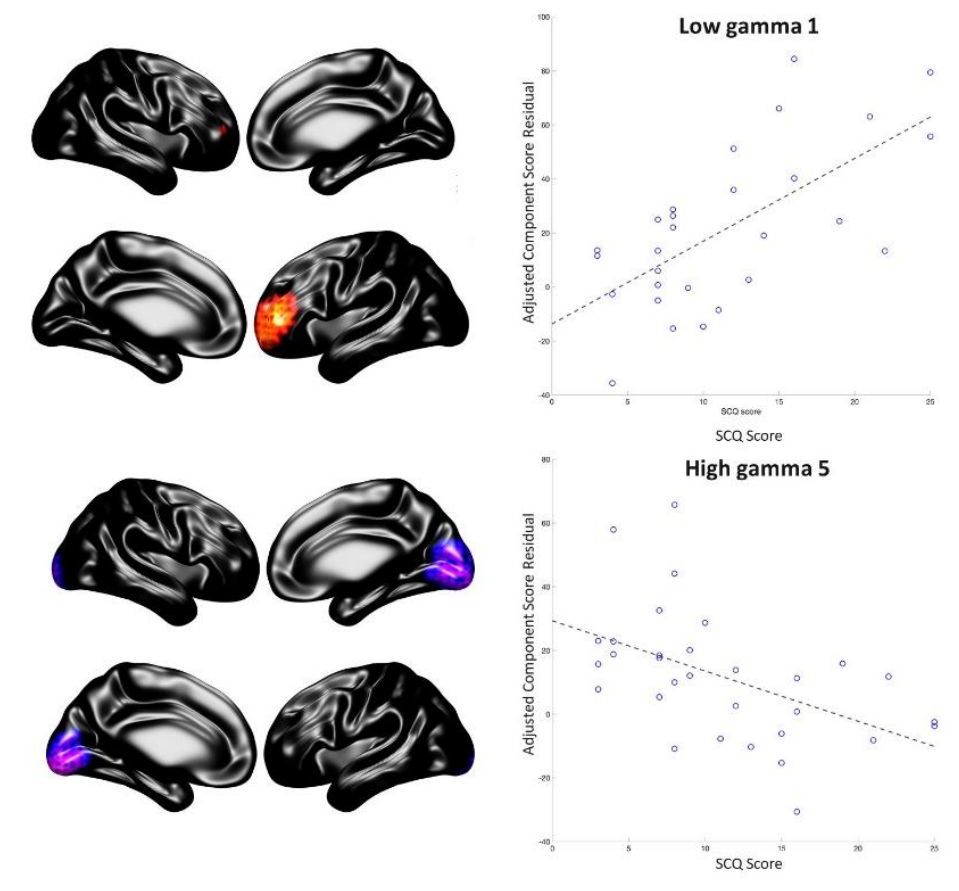

Figure 6. Relationship between SCQ score and gamma activity, controlling for age, sex, IQ and number of trials. Purple indicates reduced activity and orange indicates increased activity. Effect sizes: Low gamma $1=$ $0.72(p=0.0004)$, high gamma $5=-0.49(p=0.01)$.

\section{Functional connectivity}

Figure 7 shows the significant components identified in the analysis of functional connectivity for the between-group comparisons and the associations with IQ and neurodevelopmental symptoms. As for the analysis of source activity, those components showing significant associations with group status, IQ (shown separately for children with 22q11.2DS and controls) and ADHD/ASD symptoms in children with 22q11.2DS are shown in the figure, with red indicating a positive association and blue, a negative association. Age, sex and number of 'good' trials are included in each regression model, while IQ was added as an additional covariate for associations with neurodevelopmental symptoms. 


\section{Figure 7. Functional connectivity across the six frequency bands of interest and} associations with group status, IQ and neurodevelopmental symptoms

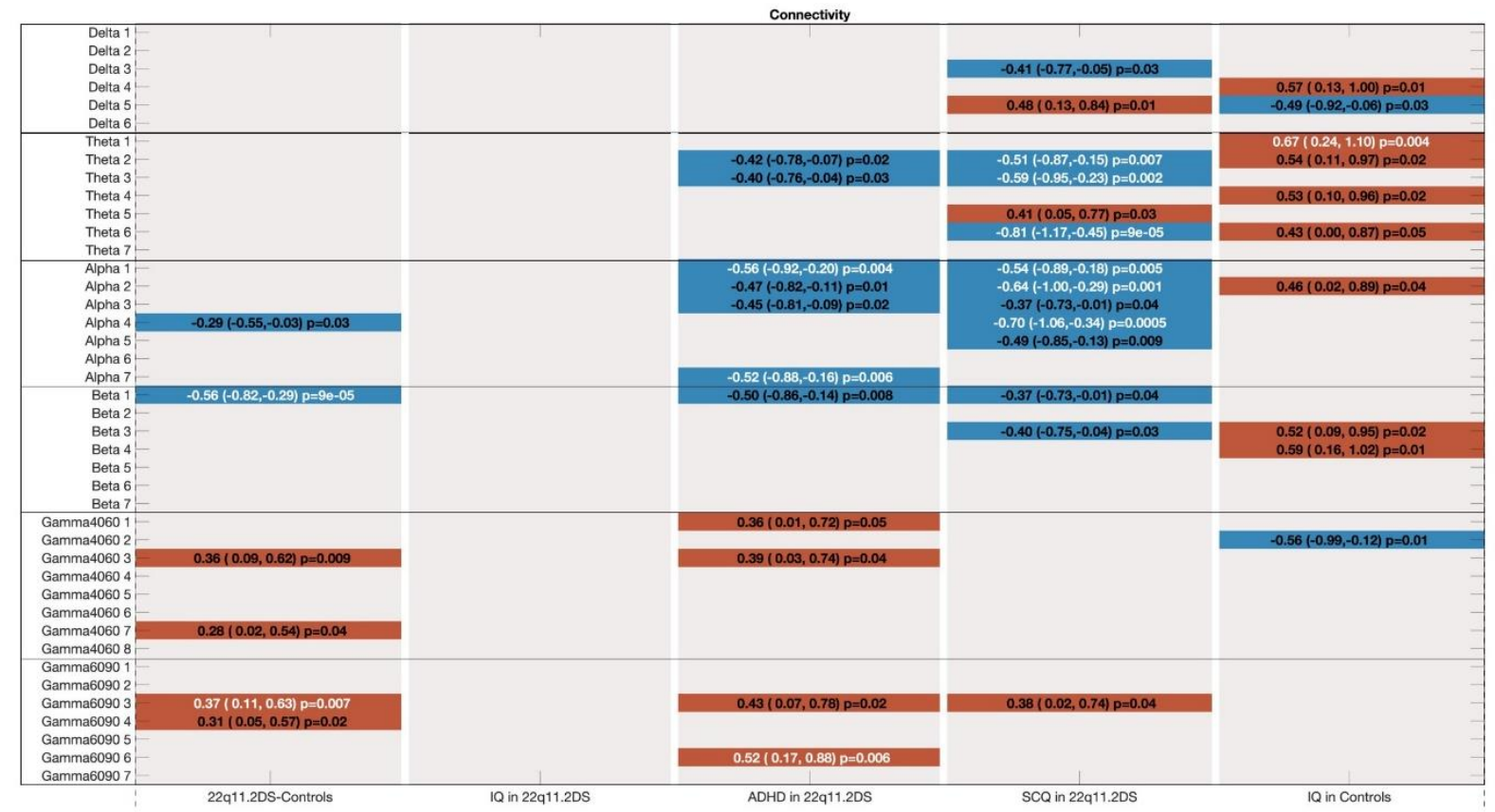

Figure 7. Significant associations between group status, $I Q$, neurodevelopmental symptoms and functional connectivity for each of the six frequency bands of interest. Components showing positive associations are shown in red, while negative associations are shown in blue. Those associations surviving Bonferroni correction for the six frequency bands studied are highlighted in white text. Associations are shown by standardised $\beta$ values, confidence intervals and $p$ values. Age and sex were included in each model as covariates, IQ was included as an additional covariate in models testing associations with SCQ and ADHD scores.

There were significant between-group differences in occipital beta and frontotemporal/frontoparietal high-gamma band functional connectivity. These differences are shown in figure 8 below. Beta band functional connectivity was lower in children with 22q11.2DS, while high gamma connectivity was higher in children with the CNV than in controls. 


\section{Figure 8. Between-group differences in functional connectivity}
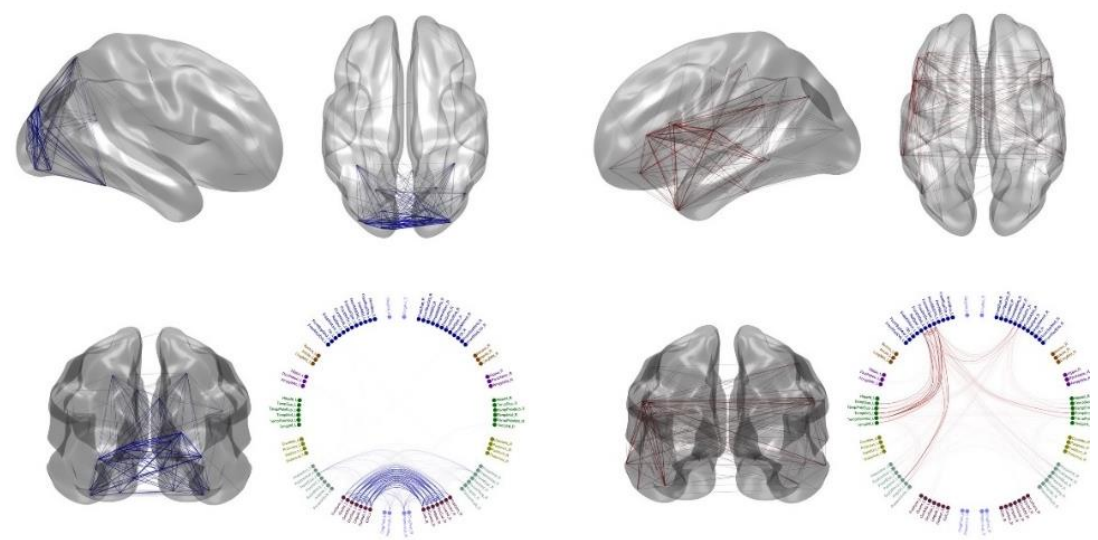

Beta 1

High gamma 3

Figure 8. Locations of the two components showing significant between-group differences in functional connectivity between children with 22q11.2DS and controls, controlling for age, sex and number of trials. Blue indicates reduced connectivity and red indicates increased connectivity. Effect sizes: Beta $1=-0.56$ $(p=0.000088)$, high gamma $3=0.37(p=0.0069)$.

There were no significant associations between functional connectivity and IQ in children with 22q11.2DS. In controls, there was a positive association between IQ and theta band functional connectivity.

Figure 9. Relationship between IQ and theta band functional connectivity in controls

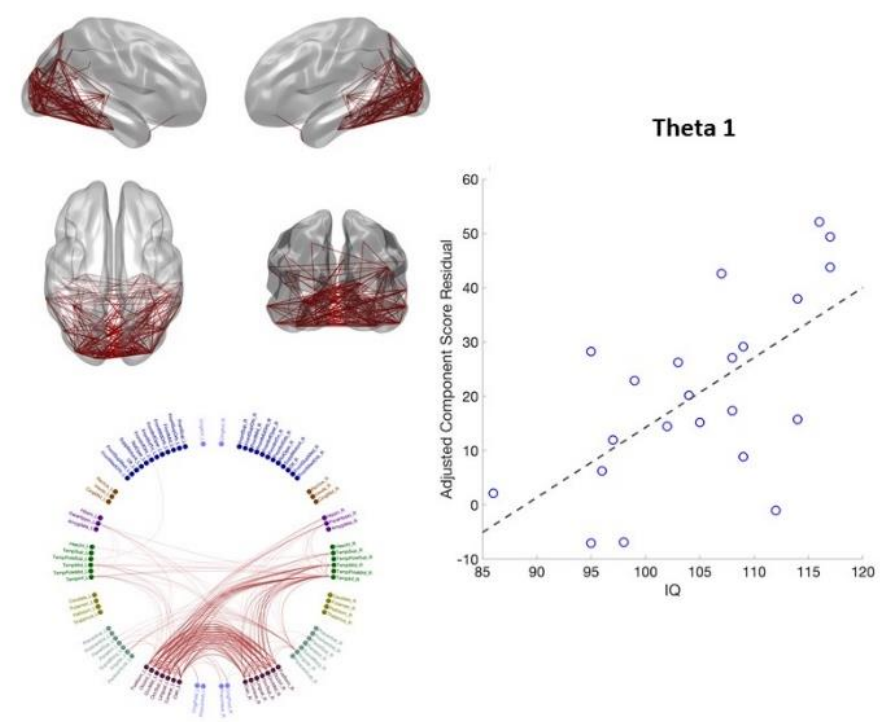

Figure 9. Relationship between IQ and functional activity in controls, controlling for age, sex and number of trials. Effect size $=0.66(p=0.004)$. Blue indicates reduced connectivity and red indicates increased connectivity 
medRxiv preprint doi: https://doi.org/10.1101/2021.09.14.21263530; this version posted September 22, 2021. The copyright holder for this preprint (which was not certified by peer review) is the author/funder, who has granted medRxiv a license to display the preprint in All rights reserved. No reuse allowed without permission.

Social communication difficulties in children with 22q11.2DS were negatively associated with alpha band functional connectivity in components comprising nodes of the posterior default mode and sensorimotor networks.

Figure 10. Associations between alpha band functional connectivity and SCQ scores
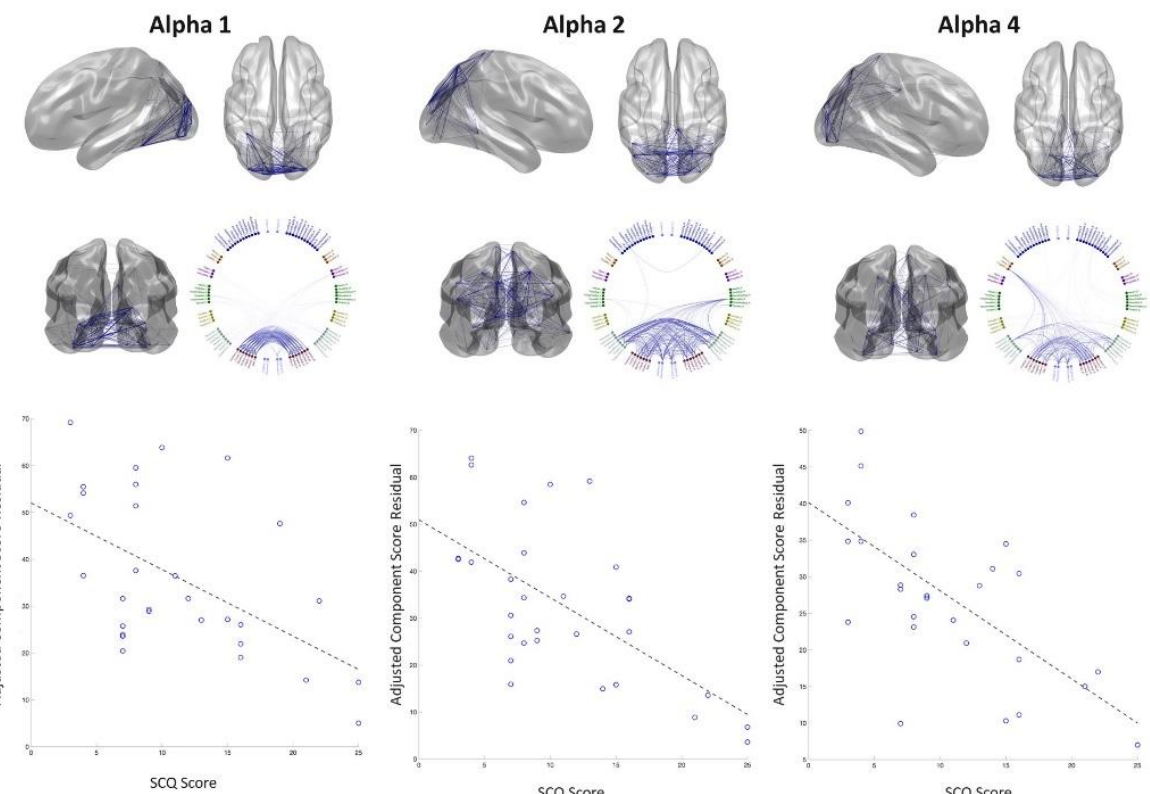

Figure 10. Relationship between alpha activity and SCQ scores, controlling for age, sex, IQ and number of trials. Effect sizes: Alpha $1=-0.54(p=0.005)$, alpha $2=-0.64(p=0.001)$, alpha $4=-0.70(p=0.0005)$. Blue indicates reduced connectivity and red indicates increased connectivity

ASD symptoms were also associated with alterations in theta band functional connectivity.

Two of these networks (theta 2 and theta 6) are broadly similar to those seen in the alpha band, while theta 3 comprises frontal, temporal and occipital nodes. 


\section{Figure 11. Associations between theta band functional connectivity and SCQ scores}
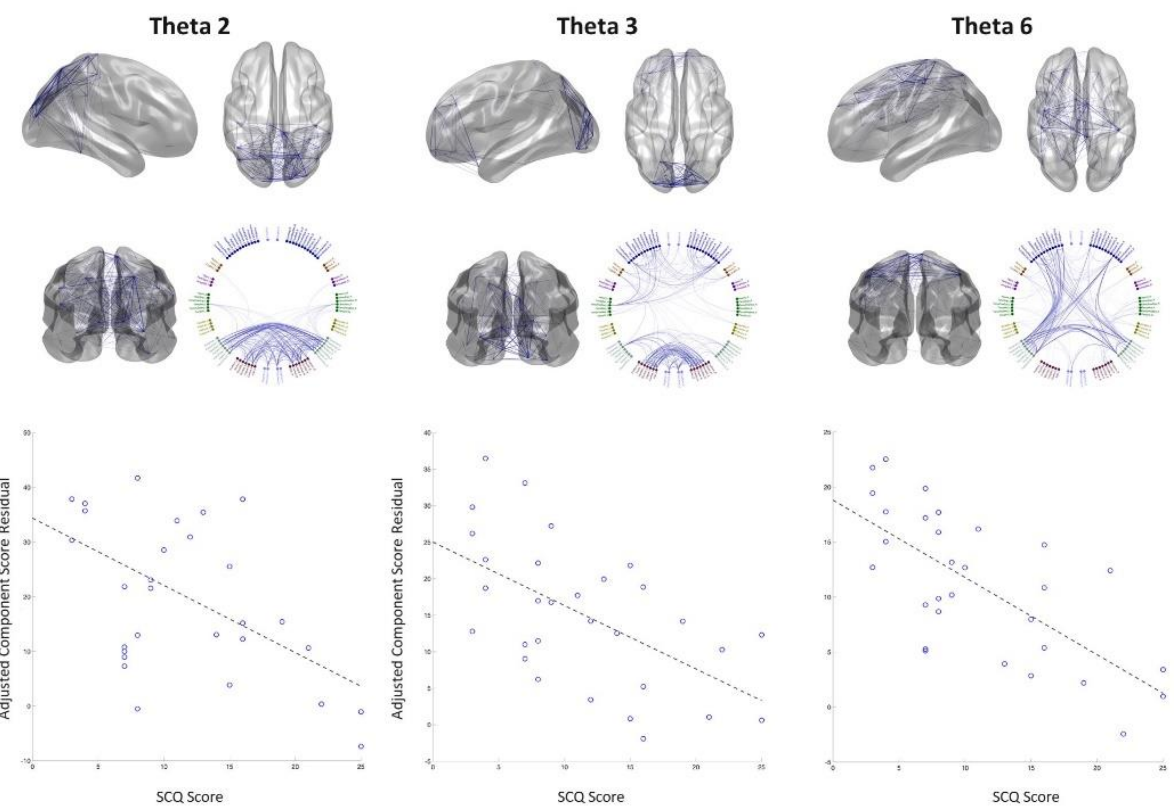

Figure 11. Relationship between theta band functional connectivity and SCQ scores, controlling for age, sex, IQ and number of trials. Theta 2 effect size $=-0.51(p=0.007)$, theta 3 effect size $=-0.59(p=0.002)$, theta 6 effect size $=-0.81(p=0.00009)$. Blue indicates reduced connectivity and red indicates increased connectivity.

Finally, ADHD symptoms were associated with increased high gamma $(60-90 \mathrm{~Hz})$ connectivity across a diffuse network including right frontotemporal, frontoparietal, temporoparietal and occipito-occipital connections. Alpha band functional connectivity was significantly reduced in two components, a posterior network consisting of occipito-occipital connections and an extended network involving multiple nodes across the brain. 


\section{Figure 12. Associations between functional connectivity and ADHD symptoms}
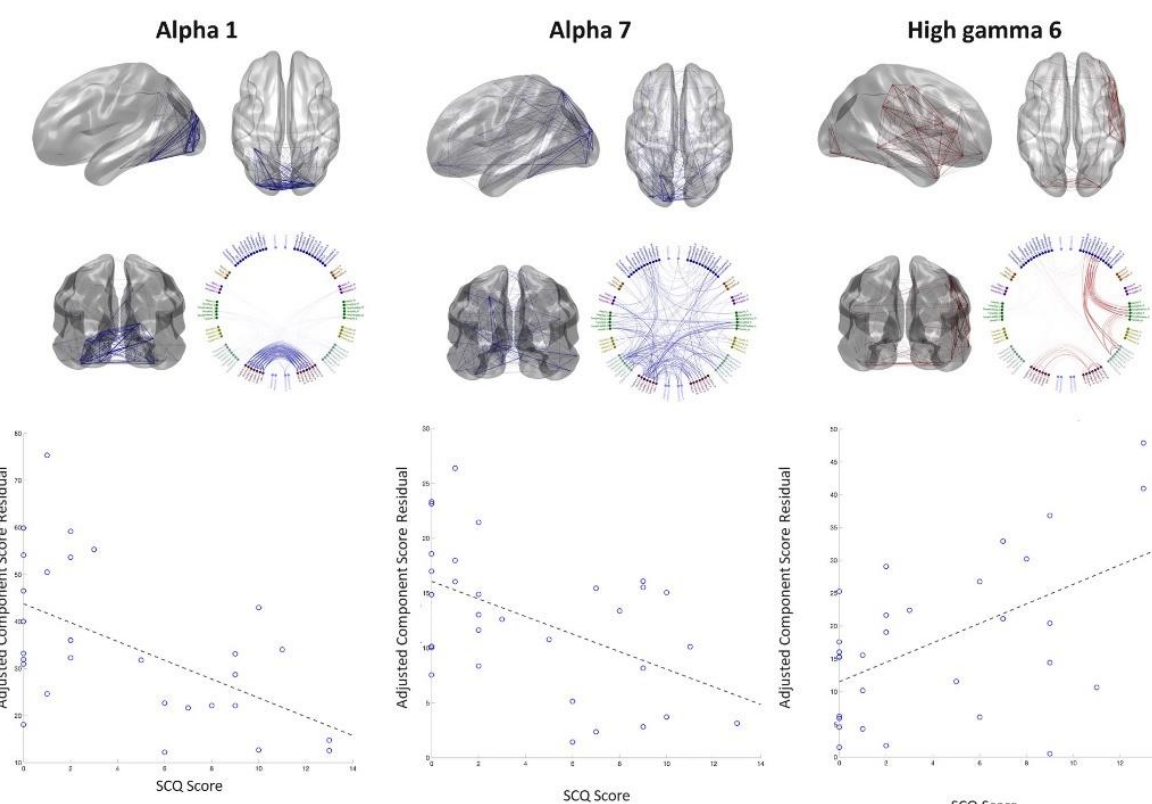

Figure 12. Relationship between functional connectivity and ADHD symptom scores, controlling for age, sex, IQ and number of trials. Alpha 1 effect size $=-0.56(p=0.004)$, alpha 7 effect size $=-0.52(p=0.006)$, high gamma 6 effect size $=0.52(p=0.006)$. Blue indicates reduced connectivity and red indicates increased connectivity.

\section{Discussion}

22q11.2DS is a genetic syndrome associated with a variable and impairing neurodevelopmental phenotype. To our knowledge, this is the first study of resting-state neural oscillatory patterns in children with 22q11.2DS and the first study to explore the associations between oscillatory activity, functional connectivity and neurodevelopmental symptoms. Using robust between-group and exploratory within-group analysis strategies, we found atypical oscillatory patterns in children with 22q11.2DS, which were associated with cognitive impairments, social communication difficulties and ADHD symptoms. Of particular note, we found increased high frequency (gamma range) activity and functional connectivity in the frontal lobes of children with 22q11.2DS, which were associated with ASD and ADHD 
medRxiv preprint doi: https://doi.org/10.1101/2021.09.14.21263530; this version posted September 22, 2021. The copyright holder for this preprint (which was not certified by peer review) is the author/funder, who has granted medRxiv a license to display the preprint in All rights reserved. No reuse allowed without permission.

symptoms respectively. Conversely, occipital gamma band activity was reduced in 22q11.2DS. Low frequency oscillatory activity and functional connectivity were also reduced in children with 22q11.2DS with reductions in low frequency functional connectivity being associated with neurodevelopmental symptoms and $\mathrm{IQ}$, particularly in posterior brain regions. Our findings are in keeping with previous functional imaging studies in 22q11.2DS which report alterations in the frontal, default mode, sensorimotor and visual networks (23-27). These networks have also been implicated in idiopathic ASD (32,58-62) and ADHD ((63-67).

High frequency oscillations in the gamma range are thought to reflect local field potentials which arise as a result of the relative balance between excitation and inhibition in local cortical circuits (68). Cellular, animal and computational models have shown that these are largely driven by the action of parvalbumin-containing interneurons which synapse on excitatory pyramidal neurons (69-74). Excitatory-inhibitory imbalance has been proposed as a common neurobiological mechanism across the spectrum of neurodevelopmental disorders seen in 22q11.2DS (35,75-77). Here, we found evidence for increased gamma activity and functional connectivity in frontal brain regions in children with 22q11.2DS, which were positively associated with the severity of ASD and ADHD symptoms. Gamma activity in the occipital lobe was lower in children with 22q11.2DS than controls and negatively associated with ASD symptoms. There are several mechanisms by which excitatory-inhibitory balance may be perturbed in 22q11.2DS. Firstly, haploinsufficency of $P R O D H$, a gene in the $22 q 11.2$ region, has been shown to affect GABA synthesis and gamma band activity in murine models (78). Secondly, these models have also found abnormal PV+ inhibitory interneuron migration in $22 q 11.2 \mathrm{DS}$, a finding that is mirrored in postmortem studies of humans with 22q11.2DS $(13-15,18,19)$. While there is little known evidence of regional brain differences in excitatory- 
medRxiv preprint doi: https://doi.org/10.1101/2021.09.14.21263530; this version posted September 22, 2021. The copyright holder for this preprint (which was not certified by peer review) is the author/funder, who has granted medRxiv a license to display the preprint in All rights reserved. No reuse allowed without permission.

inhibitory balance in 22q11.2DS, it is plausible that increased frontal and decreased occipital excitability could result in pleiotropic neurodevelopmental outcomes and psychosis risk. Indeed, increased frontal and decreased occipital gamma oscillations have been reported in patients with schizophrenia (79-81).

Low frequency oscillations are thought to facilitate long-range communication between brain regions (82). Computer simulations have further shown that low frequency amplitude envelope correlations seen in resting-state MEG studies may originate from spontaneous synchronisation mechanisms in the brain (83). Alterations in alpha, beta and theta band oscillations have been reported in ASD, ADHD and schizophrenia $(67,77,84-89)$. In this study, we found significant reductions in beta activity and functional connectivity in parietotemporal and occipital brain regions in children with 22q11.2DS. Alpha band activity was lower in children with 22q11.2DS who had lower cognitive ability while alpha band connectivity was lower in those with more severe ADHD and ASD symptoms. Theta band connectivity was also lower in those with more ASD symptoms.

The functional connectivity changes we found in children are similar to those previously reported by our research group in adult neurodevelopmental CNV carriers. (41). While there were relatively few participants with 22q11.2DS in that study $(n=14)$, analysis of the $22 q 11.2$ group alone found similar connectivity reductions as the cross-CNV analysis but in addition, a number of nodes with hyperconnectivity were identified. $80 \%$ of participants in the adult study had a DSM-IV diagnosis (including 14\% with schizophrenia) and $62 \%$ of the sample were taking medication. In the present study, while high rates of ASD and ADHD were found, none of the children had a psychotic disorder and all were free from psychotropic medication. 
medRxiv preprint doi: https://doi.org/10.1101/2021.09.14.21263530; this version posted September 22, 2021. The copyright holder for this preprint (which was not certified by peer review) is the author/funder, who has granted medRxiv a license to display the preprint in All rights reserved. No reuse allowed without permission.

Given that up to $30 \%$ of people with 22 q11.2DS develop schizophrenia during their lifetime (11), it is highly likely that a proportion of the children recruited to this study will develop psychotic symptoms in the future. Following up these children over time may yield insights into neural markers of psychosis risk.

Strengths of this study include the relatively narrow age range recruited compared to previous electrophysiological studies of CNV carriers (10-17 years), clinical and cognitive phenotyping and robust MEG analysis strategies. However, there are also a number of limitations. Due to the relative rarity of $22 \mathrm{q} 11.2 \mathrm{DS}$, the sample size is modest. Therefore without replication, the findings should be interpreted cautiously, due to the risks of both type 1 and type 2 error (90). The physical health problems associated with 22q11.2DS meant that contraindications for MRI scanning were common and it was not possible to co-register MEG data to each participant's own MRI scan. While every attempt was made to closely match the fiducial locations to those of another participant, this is not a perfect substitute for using participants' own data and this may have affected source localization. The relatively short duration of the resting-state paradigm was chosen to balance data quantity and quality, however this will have resulted in lower SNR than longer paradigms (91). Unfortunately, a longer recording would not have been feasible for the majority of children taking part in this study. Furthermore, continuous head localization was not used during data acquisition so detailed analysis of head movement and correction for this was not possible. Children in both groups found it difficult to remain still during the recordings and therefore a pragmatic approach was taken to assessing data quality with higher upper limits of head motion being tolerated than in many studies involving adults. 
medRxiv preprint doi: https://doi.org/10.1101/2021.09.14.21263530; this version posted September 22, 2021. The copyright holder for this preprint (which was not certified by peer review) is the author/funder, who has granted medRxiv a license to display the preprint in

All rights reserved. No reuse allowed without permission.

In summary, the present study investigated resting-state neural oscillatory patterns in children with a genetic syndrome associated with neurodevelopmental disorders and cognitive impairment. We observed alterations in oscillatory activity/connectivity that were associated with the severity of cognitive difficulties, ASD and ADHD symptoms. These effects were seen at both high frequencies, thought to reflect local cortical processes, and at low frequencies, thought to reflect longer-range cortical communication. These results suggest a potential neural mechanism by which the $22 q 11.2$ deletion could act to increase risk across the spectrum of neurodevelopmental disorders, involving anterior hyper- and posterior hypoconnectivity. This has implications for our understanding of 22q11.2DS, other neurodevelopmental CNVs and idiopathic neurodevelopmental disorders. In the future, longitudinal studies could shed light on how these oscillatory patterns may change during development and how they may relate to the emergence of psychotic symptoms.

\section{Declarations and conflicts of interest}

MO and MvdB have research grants from Takeda Pharmaceuticals outside the scope of the present study.

\section{Acknowledgements}

This work was supported by a Wellcome Trust ISSF Award and Clinical Research Training Fellowship to JD (102003/Z/13/Z), the Waterloo Foundation (code 918-1234) and the Baily Thomas Charitable Fund (2315/1) to MvdB and MJO, a Medical Research Council Centre Grant (No. MR/L010305/1) to MJO and the National Centre for Mental Health. The authors would like to thank Lisa Brindley, Suresh Muthukumaraswamy, Gavin Perry, Sonya Foley and Rachael 
medRxiv preprint doi: https://doi.org/10.1101/2021.09.14.21263530; this version posted September 22, 2021. The copyright holder for this preprint (which was not certified by peer review) is the author/funder, who has granted medRxiv a license to display the preprint in All rights reserved. No reuse allowed without permission.

Adams for their assistance with data collection, and Loes Koelewijn for her help with data preprocessing. They would also like to thank the charities and NHS clinics who helped to recruit participants and all of the families who participated in the study.

\section{References}

1. Hastings P, Lupski JR, Rosenberg S, Ira G (2009): Mechanisms of change in gene copy number. Nat Rev Genet 10: 551-564.

2. Rees E, Moskvina V, Owen MJ, O’Donovan MC, Kirov G (2011): De novo rates and selection of schizophrenia-associated copy number variants. Biol Psychiatry 70: 110914.

3. Botto LD, May K, Fernhoff PM, Correa A, Coleman K, Rasmussen SA, et al. (2003): A population-based study of the 22q11.2 deletion: phenotype, incidence, and contribution to major birth defects in the population. Pediatrics 112: 101-7.

4. Oskarsdottir S (2004): Incidence and prevalence of the 22q11 deletion syndrome: a population-based study in Western Sweden. Arch Dis Child.

5. Maisenbacher MK, Merrion K, Pettersen B, Young M, Paik K, lyengar S, et al. (2017): Incidence of the 22q11.2 deletion in a large cohort of miscarriage samples. Mol Cytogenet 10: 6 .

6. McDonald-McGinn DM, Sullivan KE, Marino B, Philip N, Swillen A, Vorstman JAS, et al. (2015): 22q11.2 deletion syndrome. Nat Rev Dis Prim 1: 15071.

7. Cunningham A, Hall J, Einfeld S, MJ, Owen M, van den Bree M (2020): Assessment of 
medRxiv preprint doi: https://doi.org/10.1101/2021.09.14.21263530; this version posted September 22, 2021. The copyright holder for this preprint (which was not certified by peer review) is the author/funder, who has granted medRxiv a license to display the preprint in All rights reserved. No reuse allowed without permission.

emotions and behaviour by the Developmental Behaviour Checklist in young people with neurodevelopmental CNVs. Psychol Med 1-13.

8. Morrison S, Chawner S, van Amelsvoort T, Swillen A, Vingerhoets C, Vergaelen E, et al. (2020): Cognitive deficits in childhood, adolescence and adulthood in 22q11.2 deletion syndrome and association with psychopathology. Trans/ Psychiatry 10:53

9. Niarchou M, Zammit S, van Goozen SHM, Thapar A, Tierling HM, Owen MJ, van den Bree MBM (2014): Psychopathology and cognition in children with 22q11.2 deletion syndrome. Br J Psychiatry 204: 46-54.

10. Monks S, Niarchou M, Davies AR, Walters JTR, Williams N, Owen MJ, et al. (2014): Further evidence for high rates of schizophrenia in 22q11.2 deletion syndrome. Schizophr Res 153: 231-236.

11. Schneider M, Debbané M, Bassett AS, Chow EWC, Fung WLA, Marianne B.M. van den Bree MO, et al. (2014): Psychiatric Disorders From Childhood to Adulthood in 22q11.2 Deletion Syndrome: Results From the International Consortium on Brain and Behavior in 22q11.2 Deletion Syndrome. Am J Psychiatry.

12. Karayiorgou M, Simon TJ, Gogos JA (2010): 22q11.2 microdeletions: linking DNA structural variation to brain dysfunction and schizophrenia. Nat Rev Neurosci 11: 402416.

13. Meechan DW, Tucker ES, Maynard TM, LaMantia A-S (2009): Diminished dosage of 22q11 genes disrupts neurogenesis and cortical development in a mouse model of 22q11 deletion/DiGeorge syndrome. Proc Natl Acad Sci 106: 16434-16445.

14. Meechan DW, Tucker ES, Maynard TM, LaMantia A-S (2012): Cxcr4 regulation of 
medRxiv preprint doi: https://doi.org/10.1101/2021.09.14.21263530; this version posted September 22, 2021. The copyright holder for this preprint (which was not certified by peer review) is the author/funder, who has granted medRxiv a license to display the preprint in All rights reserved. No reuse allowed without permission.

interneuron migration is disrupted in 22q11.2 deletion syndrome. Proceedings of the National Academy of Sciences. 109: 18601-18606

15. Piskorowski RA, Nasrallah K, Diamantopoulou A, Mukai J, Hassan SI, Siegelbaum SA, et al. (2016): Age-Dependent Specific Changes in Area CA2 of the Hippocampus and Social Memory Deficit in a Mouse Model of the 22q11.2 Deletion Syndrome. Neuron 89: 163176.

16. Sigurdsson T, Stark KL, Karayiorgou M, Gogos JA, Gordon JA (2010): Impaired hippocampal-prefrontal synchrony in a genetic mouse model of schizophrenia. Nature 464: 763-767.

17. Amin H, Marinaro F, De Pietri Tonelli D, Berdondini L (2017): Developmental excitatoryto-inhibitory GABA-polarity switch is disrupted in 22q11.2 deletion syndrome: a potential target for clinical therapeutics. Sci Rep 7: 15752.

18. KiehI TR, Chow EWC, Mikulis DJ, George SR, Bassett AS (2009): Neuropathologic features in adults with 22q11.2 deletion syndrome. Cereb Cortex 19: 153-164.

19. Mori T, Mori K, Fujii E, Toda Y, Miyazaki M, Harada M, Kagami S (2011):

Neuroradiological and Neurofunctional Examinations for Patients with 22q11.2 Deletion. Neuropediatrics 42: 215-221.

20. Sun D, Ching CRK, Lin A, Forsyth JK, Kushan L, Vajdi A, et al. (2018): Large-scale mapping of cortical alterations in 22q11.2 deletion syndrome: Convergence with idiopathic psychosis and effects of deletion size. Mol Psychiatry 25:1822-183

21. Ching CRK, Gutman BA, Sun D, Villalon Reina J, Ragothaman A, Isaev D, et al. (2020): Mapping Subcortical Brain Alterations in 22q11.2 Deletion Syndrome: Effects of 
medRxiv preprint doi: https://doi.org/10.1101/2021.09.14.21263530; this version posted September 22, 2021. The copyright holder for this preprint (which was not certified by peer review) is the author/funder, who has granted medRxiv a license to display the preprint in All rights reserved. No reuse allowed without permission.

Deletion Size and Convergence With Idiopathic Neuropsychiatric Illness. Am J Psychiatry 177: 589-600.

22. Villalon-Reina J, Jahanshad N, Beaton E, Toga AW, Thompson PM, Simon TJ (2013): White matter microstructural abnormalities in girls with chromosome 22q11.2 deletion syndrome, Fragile $\mathrm{X}$ or Turner syndrome as evidenced by diffusion tensor imaging. Neuroimage 81: 441-454.

23. Debbané M, Lazouret M, Lagioia A, Schneider M, Van De Ville D, Eliez S, et al. (2012): Resting-state networks in adolescents with 22q11.2 deletion syndrome: Associations with prodromal symptoms and executive functions. Schizophr Res 139: 33-39.

24. Scariati E, Schaer M, Richiardi J, Schneider M, Debbané M, Van De Ville D, Eliez S (2014): Identifying 22q11.2 Deletion Syndrome and Psychosis Using Resting-State Connectivity Patterns. Brain Topogr. 27:808-21

25. Schreiner MJ, Karlsgodt KH, Uddin LQ, Chow C, Congdon E, Jalbrzikowski M, Bearden CE (2014): Default mode network connectivity and reciprocal social behavior in 22q11.2 deletion syndrome. Soc Cogn Affect Neurosci 9: 1261-7.

26. Padula MC, Schaer M, Scariati E, Schneider M, Van De Ville D, Debbané M, Eliez S (2015): Structural and functional connectivity in the default mode network in 22q11.2 deletion syndrome. J Neurodev Disord 7: 23.

27. Mattiaccio LM, Coman IL, Schreiner MJ, Antshel KM, Fremont WP, Bearden CE, Kates WR (2016): Atypical functional connectivity in resting-state networks of individuals with 22q11.2 deletion syndrome: associations with neurocognitive and psychiatric functioning. J Neurodev Disord 8: 2. 
medRxiv preprint doi: https://doi.org/10.1101/2021.09.14.21263530; this version posted September 22, 2021. The copyright holder for this preprint (which was not certified by peer review) is the author/funder, who has granted medRxiv a license to display the preprint in All rights reserved. No reuse allowed without permission.

28. Rogdaki M, Devroye C, Ciampoli M, Veronese M, Ashok A, McCutcheon R, et al. (2021):

Striatal dopaminergic alterations in individuals with copy number variants at the

22q11.2 genetic locus and their implications for psychosis risk: a [18F]-DOPA PET study.

Mol Psychiatry. https://doi.org/10.1038/S41380-021-01108-Y

29. da Silva Alves F, Boot E, Schmitz N, Nederveen A, Vorstman J, Lavini C, et al. (2011):

Proton Magnetic Resonance Spectroscopy in 22q11 Deletion Syndrome. PLoS One 6:

e21685.

30. Singer W (1999): Neuronal synchrony: a versatile code for the definition of relations?

Neuron 24: 49-65, 111-25.

31. Wang X-J (2010): Neurophysiological and Computational Principles of Cortical Rhythms in Cognition. Physiol Rev 90: 1195-1268.

32. Datko M, Gougelet R, Huang M-X, Pineda JA (2016): Resting State Functional Connectivity MRI among Spectral MEG Current Sources in Children on the Autism Spectrum. Front Neurosci 10: 258.

33. Brodski-Guerniero A, Naumer MJ, Moliadze V, Chan J, Althen H, Ferreira-Santos F, et al. (2018): Predictable information in neural signals during resting state is reduced in autism spectrum disorder. Hum Brain Mapp 39: 3227-3240.

34. Lajiness-O'Neill R, Brennan JR, Moran JE, Richard AE, Flores A-M, Swick C, et al. (2018): Patterns of altered neural synchrony in the default mode network in autism spectrum disorder revealed with magnetoencephalography (MEG): Relationship to clinical symptomatology. Autism Res 11: 434-449.

35. Wilson TW, Wetzel MW, White ML, Knott NL (2012): Gamma-frequency neuronal 
medRxiv preprint doi: https://doi.org/10.1101/2021.09.14.21263530; this version posted September 22, 2021. The copyright holder for this preprint (which was not certified by peer review) is the author/funder, who has granted medRxiv a license to display the preprint in All rights reserved. No reuse allowed without permission.

activity is diminished in adults with attention-deficit/hyperactivity disorder: a pharmaco-MEG study. J Psychopharmacol 26: 771-777.

36. Franzen J, Heinrichs-Graham E, White M, Wetzel M, Knott N, Wilson T (2013): Atypical coupling between posterior regions of the default mode network in attentiondeficit/hyperactivity disorder: a pharmaco-magnetoencephalography study. $J$ Psychiatry Neurosci 38: 333-340.

37. Sudre G, Szekely E, Sharp W, Kasparek S, Shaw P (2017): Multimodal mapping of the brain's functional connectivity and the adult outcome of attention deficit hyperactivity disorder. Proc Natl Acad Sci U S A 114: 11787-11792.

38. Kim J, Shin K, Jung W, Kim S, Kwon J, Chung C (2014): Power spectral aspects of the default mode network in schizophrenia: an MEG study. BMC Neurosci 15: 104.

39. Chen Y-H, Stone-Howell B, Edgar JC, Huang M, Wootton C, Hunter MA, et al. (2016): Frontal slow-wave activity as a predictor of negative symptoms, cognition and functional capacity in schizophrenia. Br J Psychiatry 208: 160-167.

40. Houck JM, Çetin MS, Mayer AR, Bustillo JR, Stephen J, Aine C, et al. (2017): Magnetoencephalographic and functional MRI connectomics in schizophrenia via intraand inter-network connectivity. Neuroimage 145: 96-106.

41. Dima DC, Adams R, Linden SC, Baird A, Smith J, Foley S, et al. (2020): Electrophysiological network alterations in adults with copy number variants associated with high neurodevelopmental risk. Transl Psychiatry 10: 1-11.

42. Kendall KM, Rees E, Escott-Price V, Einon M, Thomas R, Hewitt J, et al. (2017): Cognitive Performance Among Carriers of Pathogenic Copy Number Variants: Analysis of 152,000 
medRxiv preprint doi: https://doi.org/10.1101/2021.09.14.21263530; this version posted September 22, 2021. The copyright holder for this preprint (which was not certified by peer review) is the author/funder, who has granted medRxiv a license to display the preprint in All rights reserved. No reuse allowed without permission.

UK Biobank Subjects. Biol Psychiatry 82: 103-110.

43. Angold A, Prendergast M, Cox A, Harrington R, Simonoff E, Rutter M (1995): The Child and Adolescent Psychiatric Assessment (CAPA). Psychol Med 25: 739-53.

44. American Psychiatric Association (2013): Diagnostic and Statistical Manual of Mental Disorders. American Psychiatric Association.

https://doi.org/10.1176/appi.books.9780890425596

45. Rutter M, Bailey A, Lord C (2003): The Social Communication Questionnaire. Los Angeles: Western Psychological Services.

46. Wechsler D (1999): Manual for the Wechsler Abbreviated Scale of Intelligence (WASI). Pearson.

47. Vrba J, Robinson SE (2001): Signal Processing in Magnetoencephalography. Methods 25: $249-271$.

48. Oostenveld R, Fries P, Maris E, Schoffelen J-M (2011): FieldTrip: Open source software for advanced analysis of MEG, EEG, and invasive electrophysiological data. Comput Intell Neurosci 2011: 156869.

49. Koelewijn L, Lancaster TM, Linden D, Dima DC, Routley BC, Magazzini L, et al. (2019): Oscillatory hyperactivity and hyperconnectivity in young APOE-ع4 carriers and hypoconnectivity in alzheimer's disease. Elife 8. https://doi.org/10.7554/eLife.36011

50. Luckhoo HT, Brookes MJ, Woolrich MW (2014): Multi-session statistics on beamformed MEG data. Neuroimage 95: 330-335.

51. Colclough GL, Woolrich MW, Tewarie PK, Brookes MJ, Quinn AJ, Smith SM (2016): How 
medRxiv preprint doi: https://doi.org/10.1101/2021.09.14.21263530; this version posted September 22, 2021. The copyright holder for this preprint (which was not certified by peer review) is the author/funder, who has granted medRxiv a license to display the preprint in All rights reserved. No reuse allowed without permission.

reliable are MEG resting-state connectivity metrics? Neuroimage 138: 284-293.

52. Tzourio-Mazoyer N, Landeau B, Papathanassiou D, Crivello F, Etard O, Delcroix N, et al. (2002): Automated Anatomical Labeling of Activations in SPM Using a Macroscopic Anatomical Parcellation of the MNI MRI Single-Subject Brain. Neuroimage 15: 273-289.

53. Colclough GL, Brookes MJ, Smith SM, Woolrich MW (2015): A symmetric multivariate leakage correction for MEG connectomes. Neuroimage 117: 439-48.

54. Brookes MJ, Woolrich MW, Barnes GR (2012): Measuring functional connectivity in MEG: A multivariate approach insensitive to linear source leakage. Neuroimage 63: $910-920$.

55. Phalen H, Coffman BA, Ghuman A, Sejdić E, Salisbury DF (2020): Non-negative Matrix Factorization Reveals Resting-State Cortical Alpha Network Abnormalities in the FirstEpisode Schizophrenia Spectrum. Biol Psychiatry Cogn Neurosci Neuroimaging 5: 961970.

56. Messaritaki E, Foley S, Schiavi S, Magazzini L, Routley B, Jones DK, Singh KD (2021):

Predicting MEG resting-state functional connectivity from microstructural information. Netw Neurosci 5: 477-504.

57. Berument SK, Rutter M, Lord C, Pickles A, Bailey A (1999): Autism screening questionnaire: diagnostic validity. Br J Psychiatry 175: 444-51.

58. Vandenbroucke MWG, Scholte HS, van Engeland H, Lamme VAF, Kemner C (2008): A neural substrate for atypical low-level visual processing in autism spectrum disorder. Brain 131: 1013-1024.

59. Vlamings PHJM, Jonkman LM, van Daalen E, van der Gaag RJ, Kemner C (2010): Basic 
medRxiv preprint doi: https://doi.org/10.1101/2021.09.14.21263530; this version posted September 22, 2021. The copyright holder for this preprint (which was not certified by peer review) is the author/funder, who has granted medRxiv a license to display the preprint in

All rights reserved. No reuse allowed without permission.

Abnormalities in Visual Processing Affect Face Processing at an Early Age in Autism Spectrum Disorder. Biol Psychiatry 68: 1107-1113.

60. Baruth JM, Casanova MF, Sears L, Sokhadze E (2010): Early-stage visual processing abnormalities in high-functioning autism spectrum disorder (ASD). Transl Neurosci 1: 177-187.

61. Seymour RA, Rippon G, Gooding-Williams G, Schoffelen JM, Kessler K (2019):

Dysregulated oscillatory connectivity in the visual system in autism spectrum disorder Brain, Volume 142, Issue 10, October 2019, Pages 3294- 3305.

62. Uddin LQ, Supekar K, Lynch CJ, Khouzam A, Phillips J, Feinstein C, et al. (2013): Salience Network-Based Classification and Prediction of Symptom Severity in Children With Autism Supplemental content at jamapsychiatry.com Original Investigation. JAMA Psychiatry 70: 869-879.

63. Gao F, Edden RAE, Li M, Puts NAJ, Wang G, Liu C, et al. (2013): Edited magnetic resonance spectroscopy detects an age-related decline in brain GABA levels. Neuroimage 78: 75-82.

64. Sigi Hale T, Kane AM, Kaminsky O, Tung KL, Wiley JF, Mcgough JJ, et al. (2014): Visual network asymmetry and default mode network function in ADHD: an fMRI study. Front. Psychiatry. https://doi.org/10.3389/fpsyt.2014.00081

65. Elton A, Alcauter S, Gao W (2014): Network connectivity abnormality profile supports a categorical-dimensional hybrid model of ADHD. Hum Brain Mapp 35: 4531-4543.

66. Kucyi A, Hove MJ, Biederman J, Van Dijk KRA, Valera EM (2015): Disrupted functional connectivity of cerebellar default network areas in attention-deficit/hyperactivity 
medRxiv preprint doi: https://doi.org/10.1101/2021.09.14.21263530; this version posted September 22, 2021. The copyright holder for this preprint (which was not certified by peer review) is the author/funder, who has granted medRxiv a license to display the preprint in All rights reserved. No reuse allowed without permission.

disorder. Hum Brain Mapp 36: 3373-3386.

67. Khadmaoui A, Gómez C, Poza J, Bachiller A, Fernández A, Quintero J, Hornero R (2016):

MEG Analysis of Neural Interactions in Attention-Deficit/Hyperactivity Disorder. Comput Intell Neurosci 2016: 8450241.

68. Buzsáki G, Wang X-J (2012): Mechanisms of Gamma Oscillations. Annu Rev Neurosci 35: $203-225$.

69. Sohal VS, Zhang F, Yizhar O, Deisseroth K (2009): Parvalbumin neurons and gamma rhythms enhance cortical circuit performance. Nature 459: 698-702.

70. Zhao Y, Guo T, Fiksinski A, Breetvelt E, McDonald-McGinn DM, Crowley TB, et al. (2018): Variance of IQ is partially dependent on deletion type among 1,427 22q11.2 deletion syndrome subjects. Am J Med Genet Part A 176: 2172-2181.

71. Bartos M, Vida I, Jonas P (2007): Synaptic mechanisms of synchronized gamma oscillations in inhibitory interneuron networks. Nat Rev Neurosci 8: 45-56.

72. Ghariani S, Dahan K, Saint-Martin C, Kadhim H, Morsomme F, Moniotte S, et al. (2002): Polymicrogyria in chromosome 22q11 deletion syndrome. Eur J Paediatr Neurol 6: 737.

73. Gonzalez-Burgos G, Cho RY, Lewis DA (2015): Alterations in Cortical Network Oscillations and Parvalbumin Neurons in Schizophrenia. Biol Psychiatry 77: 1031-1040.

74. Brunel N, Wang X-J (2003): What determines the frequency of fast network oscillations with irregular neural discharges? I. Synaptic dynamics and excitation-inhibition balance. J Neurophysiol 90: 415-30. 
medRxiv preprint doi: https://doi.org/10.1101/2021.09.14.21263530; this version posted September 22, 2021. The copyright holder for this preprint (which was not certified by peer review) is the author/funder, who has granted medRxiv a license to display the preprint in All rights reserved. No reuse allowed without permission.

75. Spencer KM, Nestor PG, Niznikiewicz MA, Salisbury DF, Shenton ME, McCarley RW (2003): Abnormal neural synchrony in schizophrenia. J Neurosci 23: 7407-11.

76. Uhlhaas PJ, Singer W (2012): Neuronal Dynamics and Neuropsychiatric Disorders:

Toward a Translational Paradigm for Dysfunctional Large-Scale Networks. Neuron 75: $963-980$.

77. Cornew L, Roberts TPL, Blaskey L, Edgar JC (2012): Resting-State Oscillatory Activity in Autism Spectrum Disorders. J Autism Dev Disord 42: 1884-1894.

78. Crabtree GW, Park AJ, Gordon JA, Gogos JA (2016): Cytosolic Accumulation of L-Proline Disrupts GABA-Ergic Transmission through GAD Blockade. Cell Rep 17: 570-582.

79. Grent-'t-Jong T, Gross J, Goense J, Wibral M, Gajwani R, Gumley Al, et al. (2018):

Resting-state gamma-band power alterations in schizophrenia reveal E/I-balance abnormalities across illness-stages. Elife 7. https://doi.org/10.7554/eLife.37799

80. Grent-'t-Jong T, Gajwani R, Gross J, Gumley A, Krishnadas R, Lawrie S, et al. (2020):

Association of Magnetoencephalographically Measured High-Frequency Oscillations in Visual Cortex With Circuit Dysfunctions in Local and Large-scale Networks During Emerging Psychosis. JAMA psychiatry 77: 852-862.

81. Uhlhaas PJ, Singer W (2010): Abnormal neural oscillations and synchrony in schizophrenia. Nat Rev Neurosci 11: 100-113.

82. Donner TH, Siegel M (2011): A framework for local cortical oscillation patterns. Trends Cogn Sci 15: 191-199.

83. Cabral J, Luckhoo H, Woolrich M, Joensson M, Mohseni H, Baker A, et al. (2014): Exploring mechanisms of spontaneous functional connectivity in MEG: How delayed 
medRxiv preprint doi: https://doi.org/10.1101/2021.09.14.21263530; this version posted September 22, 2021. The copyright holder for this preprint (which was not certified by peer review) is the author/funder, who has granted medRxiv a license to display the preprint in All rights reserved. No reuse allowed without permission.

network interactions lead to structured amplitude envelopes of band-pass filtered oscillations. Neuroimage 90: 423-435.

84. O’Reilly C, Lewis JD, Elsabbagh M (2017): Is functional brain connectivity atypical in autism? A systematic review of EEG and MEG studies. PLoS One 12: e0175870.

85. Deiber MP, Hasler R, Colin J, Dayer A, Aubry JM, Baggio S, et al. (2020): Linking alpha oscillations, attention and inhibitory control in adult ADHD with EEG neurofeedback. Neurolmage Clin 25: 102145.

86. Zeev-Wolf M, Levy J, Jahshan C, Peled A, Levkovitz Y, Grinshpoon A, Goldstein A (2018): MEG resting-state oscillations and their relationship to clinical symptoms in schizophrenia. Neurolmage Clin 20: 753-761.

87. Liddle EB, Price D, Palaniyappan L, Brookes MJ, Robson SE, Hall EL, et al. (2016): Abnormal salience signaling in schizophrenia: The role of integrative beta oscillations. Hum Brain Mapp 37: 1361-1374.

88. Kessler K, Seymour RA, Rippon G (2016): Brain oscillations and connectivity in autism spectrum disorders (ASD): new approaches to methodology, measurement and modelling. Neuroscience and Biobehavioral Reviews 71:601-620.

89. Larrain-Valenzuela J, Zamorano F, Soto-Icaza P, Carrasco X, Herrera C, Daiber F, et al. (2017): Theta and Alpha Oscillation Impairments in Autistic Spectrum Disorder Reflect Working Memory Deficit. Sci Rep 7: 1-11.

90. Button KS, loannidis JPA, Mokrysz C, Nosek BA, Flint J, Robinson ESJ, Munafò MR (2013): Confidence and precision increase with high statistical power. Nat Rev Neurosci 14: $585-585$. 
medRxiv preprint doi: https://doi.org/10.1101/2021.09.14.21263530; this version posted September $22,2021$. The copyright holder for this preprint (which was not certified by peer review) is the author/funder, who has granted medRxiv a license to display the preprint in All rights reserved. No reuse allowed without permission.

91. Liuzzi L, Gascoyne LE, Tewarie PK, Barratt EL, Boto E, Brookes MJ (2017): Optimising experimental design for MEG resting state functional connectivity measurement.

Neuroimage 155: 565-576. 